\title{
Śpiące języki, czyli słów kilka o sytuacji językowej rdzennych mieszkańców Australii (na przykładzie języka gamilaraay z Nowej Południowej Walii)
}

\section{Wstęp}

Niniejszy artykuł dotyczy sytuacji językowej rdzennych mieszkańców Australii i rozwijającej się dynamicznie nowej gałęzi językoznawstwa, jaką jest rewitalistyka (revival linguistics, por. Zuckermann, Walsh 2011; Giacon 2008). Ten rodzaj językoznawstwa badający proces odzyskiwania języka (language reclamation) uśpionego, to znaczy takiego, którym nikt już nie mówi na co dzień, łączy studia nad nabywaniem języka ojczystego z badaniami poświęconymi nauce języka obcego (Zuckermann 2013). Za przykład języka budzonego właśnie ze snu posłuży mi gamilaraay ${ }^{1}$, aborygeński język z rodziny pama-njungaskiej (Pama-Nyungan), używany w przeszłości na terenie Nowej Południowej Walii, nauczany obecnie m.in. w Australian National University (ANU) w Canberze i w University of Sydney ${ }^{2}$ W części pierwszej artykułu podana zostanie klasyfikacja języków według ich żywotności. W części drugiej zaprezentowana zostanie sytuacja językowa Australii. W części trzeciej podam definicję rewitalistyki oraz krótkie uzasadnienie jej powstania. Część czwarta będzie próbą odpowiedzi na pytanie, czy jest nam potrzebne zróżnicowanie językowe. Część piąta stanowić będzie opis konkretnych działań podejmowanych na rzecz odrodzenia języka gamilaraay.

1 Znany także jako kamilaroi bądź gamilaroi (por. Lewis et al. (red.) 2014 lub Bęben 2012).

2 Warto zauważyć, że niewiele języków aborygeńskich nauczanych jest na poziomie uniwersyteckim (zob. Troy, Walsh 2010, s. 179). 


\section{Klasyfikacja języków według ich żywotności}

$\mathrm{Na}$ świecie jest teraz ok. 7000 języków, z tego ponad 30\% jest zagrożonych wyginięciem (Lewis et al. (red.) 2014). Ze względu na żywotność rozróżnia się języki: a) niezagrożone (safe), które stanowią ok. 66\% wszystkich języków (Lewis et al. (red.) 2014), b) zagrożone (endangered), c) umierające (dying/ moribund) i d) wymarłe (extinct). W tej ostatniej kategorii wydzielić możemy podkategorię języków uśpionych lub zahibernowanych (dormant, sleeping bądź hybernating languages, por. Zuckermann 2013). Są to języki, którymi nikt nie posługuje się na co dzień, ale są one w wystarczającym stopniu udokumentowane, żeby możliwa była próba ich odzyskania. Do rewitalizacji uśpionego języka potrzebne są — oprócz dokumentacji — zainteresowanie, zarówno ze strony samej wspólnoty ${ }^{3}$, jak i językoznawców, oraz pieniądze (zob. np. Cavanagh 2005).

Większość języków na świecie (ok. 96\%, Crystal 2010, s. 380) to języki o niezbyt dużej liczbie użytkowników (poniżej 1000 000). Wystarczy spojrzeć na Nową Gwineę, gdzie 10 milionów osób mówi ponad 1150 językami (Evans 2010, s. 11) - czyli średnio na jeden język przypada tam mniej niż 10000 osób — żeby zrozumieć, jak wiele języków na świecie zagrożonych jest wyginięciem. Brak źródeł pisanych, popularność języka angielskiego bądź opartych na nim języków kreolskich i co za tym idzie - wciąż zmniejszająca się liczba użytkowników sprawiają, że mniej więcej co dwa tygodnie umiera jeden język (Evans 2010, s. xviii). Jak pisze Evans (2010, s. xxii), ,a major cause of language loss is the belief that everything wise and important can be, and has been, said in English" [główną przyczyną wymierania języków jest przekonanie, że wszystko, co ważne i mądre, może być powiedziane lub zostało już powiedziane po angielsku] ${ }^{4}$. Tej dominacji języka angielskiego, zwłaszcza w świecie nauki, od lat przeciwstawia się w swoich pracach Anna Wierzbicka (zob. szczególnie 2010, 2014), ostatnio proponując także zastosowanie swojej metody badań nad znaczeniem naturalnego metajęzyka semantycznego do dokumentacji języków zagrożonych: „we argue that the list of semantic primes and their grammar should be in every field linguist's backpack" [uważamy, że lista podstawowych jednostek semantycznych wraz z łączącą je gramatyką powinna znaleźć się w plecaku każdego językoznawcy zajmującego się dokumentacją języków] (Goddard, Wierzbicka 2014, s. 83).

${ }^{3}$ Mowa tutaj nie o wspólnocie językowej — której w obliczu braku języka nie ma i być nie może - lecz o wspólnocie kulturowej. Istnienie niezależnej od języka kultury aborygeńskiej jest potwierdzone przez wielu badaczy (por. Stockton 2008, s. 48).

${ }^{4}$ Wszystkie thumaczenia cytatów angielskich są mojego autorstwa (Z.B.S.). 


\section{Sytuacja językowa Australii}

Szacuje się, że w XVIII wieku, w momencie przybycia na kontynent białego człowieka, Australię zamieszkiwało ok. 600-700 tysięcy Aborygenów (Bęben 2012, s. 12), którzy mówili ok. 500 językami (Crystal 2010, s. 334). Z tych 500 języków tylko połowa, tj. 250, została udokumentowana, a jedynie 18 języków ma dziś status języków niezagrożonych wyginięciem (Eades 2013, s. 80). Trzeba pamiętać, że posługiwanie się językami rdzennymi było w Australii przez wiele lat tępione (przynajmniej do lat siedemdziesiątych XX wieku, zob. Cavanagh 2005, s. 14; Walsh 1993, s. 2; Dębski 2009, s. 36). Aby uniemożliwić przekazywanie dalej kultury i języka, dzieci były zabierane z domów rodzinnych i umieszczane w sierocińcach. Ta bestialska polityka, która doprowadziła nie tylko do wyginięcia wielu języków rdzennych, lecz także do utraty kontaktu z przeszłością, zagubienia, a co za tym idzie - ogólnej degrengolady społecznej wielu ludzi, była podyktowana chęcią ucywilizowania Aborygenów. Pokolenie osób, które $\mathrm{w}$ ten sposób zostały okradzione z dzieciństwa, nosi nazwę stolen generation skradzionego pokolenia ${ }^{5}$. Obecnie większość rdzennych mieszkańców Australii posługuje się na co dzień odmianą języka angielskiego, tzw. Aboriginal English (zob. Eades 2013). Spora grupa, głównie na północy i zachodzie Australii, mówi w kriol, języku kreolskim, który powstał na bazie języka angielskiego i języków aborygeńskich ${ }^{6}$. Rdzenne języki Australii, które mają najwięcej użytkowników, to grupa języków yolngu, języki tiwi, gunwinggu i kala lagaw na wybrzeżu północnym oraz warlipiri, aranda i pitjantjatjara $\mathrm{w}$ pustynnym rejonie centralnym (Bęben 2012, s. 21-22). Pozostałe języki mają przeważnie mniej niż 1000 użytkowników, niektóre używane są tylko przez starsze pokolenie (dzieci i młodzież wolą używać języka angielskiego lub języka kriol). Jak pisze Bęben (2012, s. 23), tylko ok. 10\% mieszkańców Australii uważających się za Aborygenów lub mieszkańców Wysp Cieśniny Torresa mówi językami rodzimymi. W Nowej Południowej Walii, gdzie nie zachował się w całości żaden język aborygeński, sytuacja jest o wiele gorsza. Jak podają Troy i Walsh (2010, s. 175), z 138506 Aborygenów zamieszkujących ten stan tylko 804 osoby (tj. $0,58 \%$, czyli nieco ponad pół procenta) posługują się językami aborygeńskimi. Bęben (2012, s. 23) zauważa, że języki obejmujące niegdyś największą powierzchnię Nowej Południowej Walii, czyli wiradhuri i kamilaroi (gamilaraay), są już praktycznie wymarłe. Jak się przekonamy (por. punkt 5), ten drugi ma jeszcze szansę się odrodzić.

5 Dopiero w 2008 (sic!) premier Australii Ken Rudd oficjalnie przeprosił za to rdzennych mieszkańców Australii (zob. np. Dębski 2009, s. 39).

${ }^{6}$ Ethnologue podaje, że kriol ma ok. 10 tysięcy użytkowników (Lewis et al. (red.) 2014). 


\section{Co to jest rewitalistyka?}

Rewitalistyka językoznawcza, czyli revival linguistics, jest gałęzią językoznawstwa, która zajmuje się przywracaniem do życia wymarłych języków. Na podstawie starych źródeł (w przypadku języków aborygeńskich są to najczęściej dziewiętnastowieczne zapiski misjonarzy) podejmowane są próby tworzenia nowych tekstów, np. bajek czy pieśni, opracowywane są słownik i gramatyka, a następnie języka uczy się w szkołach i na kursach. Oczywiście, taki sklejany z kawałków język nieuchronnie narażony jest na hybrydyczność, w przypadku języków australijskich będą to przede wszystkim zapożyczenia i kalki - fonetyczne, semantyczne, morfologiczne, składniowe - $z$ aborygeńskiego angielskiego. Jak pisze Ghil'ad Zuckermann, badacz specjalizujący się w odzyskiwaniu języków: „Revivalistics combines scientific studies of native language acquisition and foreign language learning: language reclamation is the most extreme case of foreign language learning" [Rewitalistyka łączy badania nad akwizycją języka rodzimego z badaniami nad uczeniem się języka obcego: odzyskiwanie języka jest najbardziej krańcowym przypadkiem uczenia się języka obcego] (Zuckermann et al. 2014, s. 56). Zuckermann uważa Australię za kraj, w którym dokonywano językobójstwa (linguicide) na niespotykaną nigdzie indziej na świecie skalę i postuluje stworzenie prawa do języka (Native Tongue Title), na wzór wprowadzonego w 1993 roku prawa do ziemi (Native Title), które umożliwiło wspólnotom aborygeńskim odzyskanie części ziem utraconych na skutek grabieżczej polityki białych osadników: „We argue that the Australian Government ought to compensate Indigenous people not only for the loss of tangible land, but also for the loss of intangible language" [Uważamy, że rząd powinien wprowadzić rekompensatę dla rdzennych mieszkańców Australii obejmującą nie tylko utratę materialnej ziemi, ale także utratę niematerialnego języka] (Zuckermann et al. 2014, s. 56) ${ }^{7}$.

\section{Dlaczego ważne jest odzyskanie uśpionego języka?}

Crystal (2010, s. 384) pisze o pięciu ważnych powodach, dla których powinniśmy zajmować się ginącymi językami. Jak pokazują studia nad ewolucją, do przetrwania potrzebne jest zróżnicowanie gatunków. Podobnie jest w przypadku kultur oraz języków, które człowiek stworzył jako odpowiedź na różne warunki

7 Ciekawy byłby opis konkretnych metod i technik używanych przez językoznawców przy rewitalizacji języków uśpionych. Wykracza on jednak poza skromne ramy niniejszego artykułu. 
życia. Języki, zwłaszcza te niewielkie, są często niedocenianym źródłem wiedzy o świecie ${ }^{8}$. W kategoriach leksykalnych języków aborygeńskich znajdziemy informacje na temat źródeł pozyskiwania jedzenia czy sposobów przeżycia w trudnych warunkach (por. Zuckermann 2013). Język jest także symbolem, nośnikiem naszej tożsamości, tym, co odróżnia 'nas-swoich' od 'innych-obcych'. Język przechowuje w sobie nie tylko zwyczaje, wierzenia i kulturę, pozwala nam także zajrzeć w głąb historii, zarówno osobistej, jak i narodowej. Brak języka oznacza więc utratę kontaktu z przeszłością. Ginące języki są również ogromnie ważne dla językoznawców, ponieważ mogą powiedzieć nam wiele o ludzkich zdolnościach językowych — jak zauważa Crystal (2010, s. 385), gdyby afrykańskie języki z rodziny khoisan wyginęły przed opisaniem ich przez językoznawców, to nawet nie wiedzielibyśmy, że ludzie mogą się komunikować za pomocą mlasków.

Wszystkie wymienione wyżej powody są równie ważne w przypadku języków przywracanych do życia. Najważniejszy z nich jednak to próba odbudowania kontaktu z przeszłością po to, by przywrócić rdzennym mieszkańcom Australii świadomość ich etnicznej wyjątkowości, ich kulturową tożsamość (zob. Giacon 2010, s. 413). Dla Aborygenów opowieść związana z jakimś miejscem ma często większą wartość niż samo miejsce (Bęben 2012, s. 399), utrata języka wiąże się więc z głębokim poczuciem straty. W rdzennych kulturach Australii ważna jest więź między językiem a ziemią (Stockton 2008, s. 75) — każdy obszar geograficzny ma sobie tylko przypisany język, stąd powszechna wśród Aborygenów wielojęzyczność. Jak pisze Evans (2010, s. 9), znajomość nawet sześciu języków była w społecznościach aborygeńskich normą. Przechodząc przez rzekę albo wchodząc na wzgórze, Aborygeni zmieniali język, którym się posługiwali (Evans 2010, s. 8). Odzyskanie języka oznacza więc dla nich odzyskanie łączności z ziemią, nadanie sensu otaczającej ich rzeczywistości: „The revival of sleeping Aboriginal languages can result in personal, educational and economic empowerment, sense of pride and higher selfesteem of people who have lost their heritage and purpose in life" [Odrodzenie śpiących aborygeńskich języków może skutkować osobistym, edukacyjnym i ekonomicznym wzmocnieniem, większym poczuciem dumy i własnej wartości u ludzi, którzy utracili swoje kulturowe dziedzictwo i cel w życiu] (Zuckermann, Walsh 2011, s. 119).

Rewitalizacja języka ma także wymiar praktyczny, pozwala ludziom pogodzić się z przeszłością, a co za tym idzie - przyczynia się do ich lepszego zdrowia psychicznego i, jak uważa Zuckermann (2013), może wpłynąc na zmniejszenie nękających aborygeńskie społeczności plag pijaństwa i przestępczości. Może również mieć wpływ na polepszenie sytuacji ekonomicznej wspólnot aborygeń-

${ }^{8}$ Evans (2010, s. 21) pisze o pewnym gatunku pytona (Morelia oenpellensis), który został uznany za odrębny gatunek przez naukowców dopiero w 1977 roku, a tymczasem aborygeński język kunwinjku dawno miał dla niego osobną nazwę (nawaran). 
skich: odradzające się wraz z językiem dawne zwyczaje i praktyki zwiększają zainteresowanie turystów danym regionem, a przez to przyczyniają się do jego wzrostu gospodarczego.

\section{Odrodzenie gamilaraay}

Gamilaraay należy do największej australijskiej rodziny językowej Pama-Nyungan, która obejmuje całe terytorium Australii poza terytorium północnym (Ziemia Arnhema). Jest to język z odmiany południowo-wschodniej Pama-Nyungan, z podrodziny wiradhuric (Hammarström et al. 2014). Gamilaraay używany był na północy Nowej Południowej Walii, głównie w okolicach miasteczek Walgett, Goodooga, Toomalah-Boggabilla i Moore ${ }^{9}$. Nazwa gamilaraay jest zrostem dwóch słów w tym języku: gamil 'nie' i araay 'mający', czyli ‘taki, w którym na nie mówi się gamil' (jest to dość powszechna procedura nazywania języków aborygeńskich, które częstokroć musiały współwystępować z kilkoma innymi językami na niewielkim terytorium i odróżniane były na podstawie pewnych charakterystycznych słów, por. yuwaalaraay — 'taki, w którym na nie mówi się yuwaal').

Użycie gamilaraay wśród krajowców malało stopniowo już od czasu pierwszych kontaktów z białymi, tj. od lat trzydziestych XIX wieku. Tak pisze na ten temat Tatiana Kamińska (2006):

Od roku 1837 ludzie Kamilaroi żyli w atmosferze oblężenia i panicznego strachu o swoje życie. Ucierpieli od białych więcej niż inne plemiona, gdyż zajmowali ziemie żyzne, dogodne dla hodowli bydła i roślin. [...] Rok 1905 był rokiem ostatniego wielkiego zgromadzenia (bora) szczepu Kamilaroi. [...] wraz ze śmiercią starszych umierały tradycje plemienia i jego język. Publicznie Aborygeni musieli rozmawiać po angielsku, w prywatnych domach coraz rzadziej mówili językiem gamilaraay. Profesor Wurm ${ }^{10} \mathrm{z}$ ANU, badający dzieje szczepu, spotkał ostatniego Aborygena płynnie mówiącego tym językiem w 1955 roku. [...] Młode pokolenie Kamilaroi nie zna swojego języka.

Główne źródła na temat języka gamilaraay to teksty utalentowanego językowo angielskiego misjonarza Williama Ridleya $(1855,1856,1875)$, a także artykuły geodety i antropologa amatora Roberta Mathewsa $(1902,1903)$. Niewiele jest

9 W literaturze przedmiotu często spotkać można nazwę gamilaraay yuwaalaraay. Gamilaraay i yuwaalaraay uważane są dziś za dialekty jednego języka (mają ok. 70\% wspólnego słownictwa, por. Austin 2008, s. 38). Ponieważ yuwaalaraay posiada więcej materiałów archiwalnych (taśm i zapisków), jest wykorzystywany przy rekonstrukcji gamilaraay. Z kolei ten ostatni ma o wiele większą populację potencjalnych użytkowników, stąd tylko jego naucza się w szkołach (Giacon 2007, s. 89). Ethnologue w ogóle nie wymienia yuwaalaraay jako odrębnego języka (Lewis et al. (red.) 2014).

${ }^{10}$ Chodzi zapewne o profesora Stephena Wurma. 
za to nagrań sporządzonych przez profesjonalnych językoznawców w XX wieku (zob. Austin 2008). W roku 1955 wspomniany wyżej Stephen A. Wurm w rozmowie z 95-letnim Peterem Langiem z Boggabilla, ostatnim mówiącym w gamilaraay człowiekiem, zebrał ok. 12 minut nagrań i 44 strony zapisków (Austin 2008, s. 10). W latach siedemdziesiątych XX wieku sporządzone zostały także zapisy na taśmie magnetofonowej dialektu yuwaalaraay, na których podstawie została wydana gramatyka (Williams 1980). W latach dziewięćdziesiątych powstały dwa słowniki (Austin 1992, 1994), ten ostatni został następnie zamieszczony w internecie (Austin, Nathan 1996) - tym samym gamilaraay został jednym z pierwszych języków aborygeńskich, który zaistniał w sieci. Od 1994 roku nad rewitalizacją języka gamilaraay pracuje John Giacon ${ }^{11}$, autor wielu artykułów (np. Giacon 2007, 2008, 2010), słownika (Ash, Giacon, Lissarague 2003) oraz podręczników do nauki tego języka (Giacon, Betts 1999; Giacon 2011).

To prawda, że ostatni biegły użytkownik języka gamilaraay, Peter Lang, zmarł w 1956 roku (Austin 2006, s. 438) - John Giacon, który w latach dziewięćdziesiątych pracował $\mathrm{z}$ Wujem Tedem Fieldsem z Walgett, pamiętającym z dzieciństwa dialekt yuwaalaraay, powiedział mi, że Ted Fields znał nie więcej niż 1000 pojedynczych słów. Nieprawdą jednak jest, że obecnie młodzi Kamilarojczycy nie znają swojego języka. Od lat dziewięćdziesiątych uczony jest on bowiem, z dość dobrym skutkiem, w szkołach podstawowych i średnich w Walgett, Goodooga i Toomelah-Boggabilla (Giacon 2007, s. 89). Lektoraty gamilaraay na University of Sydney oraz na ANU otwarte są nie tylko dla studentów, lecz także dla wszystkich rdzennych mieszkańców Australii zainteresowanych tym językiem. Organizowane są warsztaty dla dorosłych oraz kursy dla nauczycieli (Giacon 2007, s. 94). Oprócz słowników i podręczników do nauki języka wydano już kilka książeczek dla dzieci oraz płytę CD z piosenkami w gamilaraay (Giacon, McGregor 2003). Ważną rolę w propagowaniu tego języka wśród młodych ludzi odgrywa też strona internetowa (http://www.yuwaalaraay.org (dostęp: 19 grudnia 2015)), na której oprócz słownika znaleźć można piosenki, gry i krótkie historyjki w gamilaraay oraz ich tłumaczenie na angielski. W grudniu 2014 uruchomiona została mobilna aplikacja zawierająca interaktywny słownik gamilaraay z wymową (https://itunes.apple.com/au/app/ma-gamilaraay/id935546616?mt=8 (dostęp: 19 grudnia 2015)). Jak powiedział mi John Giacon, podejmowane są próby przeprowadzania pewnych obrzędów (np. chrzcin i pogrzebów) w tym języku, a dzieciom nadawane są tradycyjne imiona (zob. także Giacon 2007, s. 95).

11 Obecnie John Giacon uczy gamilaraay na University of Sydney oraz na ANU w Canberze. W 2014 roku obronił doktorat poświęcony gamilaraay (A grammar of Yuwaalaraay and Gamilaraay: A description of two New South Wales languages based on 160 years of records, ANU). 


\section{Podsumowanie}

Sytuacja rdzennych mieszkańców Australii pozbawionych swojego języka, a co za tym idzie - ogromnej części swojej kultury, na skutek świadomie uprawianego w tej części świata językobójstwa, czy nawet — jak chce Zuckermann (2013) — glottofagii, jest diametralnie różna od naszej. Oto bowiem ludziom żyjącym od prawie stu lat w swoistej pustce językowej, ludziom pozbawionym tego, co nam wydaje się tak oczywiste, ciągłości i trwania języka ojczystego, przekazywanego z pokolenia na pokolenie, proponuje się powrót do korzeni, które wydawały się już na zawsze utracone. Trudno o bardziej radykalną zmianę zachowań językowych. Ludziom, którzy całe życie posługiwali się językiem angielskim, dodajmy tu, aborygeńskim angielskim stygmatyzowanym jako niepoprawny, proponuje się wyprawę w przeszłość, wyprawę, która może im pomóc odzyskać swoje miejsce w świecie, świadomość swojej kulturowej odrębności, swoją etniczną tożsamość.

Czy ta wyprawa się powiedzie? Czy z rozproszonych szczątków języka uda się odtworzyć jego kształt, a co najważniejsze — tchnąć weń życie? Czy przychodzące na świat dzieci plemienia Gamilaraay będą słyszały wokół siebie język swoich przodków i będą przekazywały go dalej swoim dzieciom? Czy będą umiały dostrzec wartość posiadania swojego własnego ojczystego języka, czy też będą wolały posługiwać się językiem angielskim? To zależy nie tylko od samych zainteresowanych, lecz także od językoznawców, ich zaangażowania w dokumentację i odzyskiwanie ginących języków oraz pieniędzy, które uda im się na ten cel pozyskać (por. Giacon 2007). Jak dowodzi przykład odzyskanego po prawie stu pięćdziesięciu latach aborygeńskiego języka kaurna (Amery 2011; Troy, Walsh 2010, zob. także Crystal 2010: 387), jest to możliwe.

\section{Bibliografia}

Amery R. (2011), Taking to the airwaves. A strategy for language revival, [w:] Proceedings of the 42nd Australian Linguistic Society Conference, red. M. Ponsonnet, L. Dao, M. Bowler, Canberra, s. 5-26.

Ash A., Giacon J., Lissarague A. (2003), Gamilaraay, Yuwaalaraay and Yuwaalayaay Dictionary, Alice Springs.

Austin P. (1992), A Dictionary of Gamilaraay, Melbourne.

Austin P. (1994), A Reference Dictionary of Gamilaraay, Melbourne.

Austin P. (2006), Gamilaraay, [w:] K. Brown, S. Ogilvie, Concise Encyclopedia of Languages of the World, Amsterdam.

Austin P. (2008), The Gamilaraay (Kamilaroi) language, Northern South Wales - a brief history of research, [w:] Encountering Aboriginal Languages: Studies in the History of Australian Linguistics, red. B. McGregor, Canberra, s. 37-58.

Austin P.K., Nathan D. (1996), Kamilaroi/ Gamilaraay Web Dictionary, http://www.dnathan.com/ language/gamilaraay/dictionary/GAMDICTF.HTM (dostęp: 19 grudnia 2015).

Bęben W. (2012), Aborygeni, pierwsi nomadzi. Życie i kultura, Gdańsk. 
Cavanagh P. (2005), It Makes You Proud to Be You: A Report on the Yuwaalaraay Language Program at St Joseph's, Walgett, Strathfield.

Crystal D. (2010), The Cambridge Encyclopaedia of Language, Cambridge.

Dębski R. (2009), Dwujęzyczność angielsko-polska w Australii. Języki mniejszościowe w dobie globalizacji i informatyzacji, Kraków.

Eades D. (2013), Aboriginal Ways of Using English, Canberra.

Evans N. (2010), Dying Words. Endangered Languages and What They Have to Tell Us, Chichester.

Giacon J. (2007), Garay yugali, walanbala burranbali. Celebrating language, and making it stronger, [w:] Strengthening Languages: Proceedings of the Inaugural Indigenous Languages Conference 2007, red. R. Amery, J. Nash, Adelaide, s. 89-96.

Giacon J. (2008), Associated eating and movement: Further examination of Yuwaalaraay Gamilaraay verb suffixes, [w:] Morphology and Language History: In Honour of Harold Koch, red. C. Bowern, L. Miceli, B. Evans, Amsterdam, s. 107-121.

Giacon J. (2010), The development of the Gamilaraay, Yuwaalaraay, and Yuwaalayaay dictionary, [w:] J. Hobson, K. Lowe, S. Poetsch, M. Walsh, Re-awakening Languages: Theory and Practice in the Revitalisation of Australia's Indigenous Languages, Sydney, s. 402-417.

Giacon J. (2011), Garay Guwaala. Talk the language (skrypt do nauki języka gamilaraay).

Giacon J., Betts M. (1999), Yaama maliyaa, Yuwaalaraay - Gamilaraay: An Aboriginal Languages Textbook, Walgett.

Giacon J., McGregor B. (2003), Yugal: Gamilaraay \& Yuwaalaraay Songs, Tamworth.

Goddard C., Wierzbicka A. (2014), Semantic fieldwork and lexical universals, „Studies in Language" $38 / 1$, s. 80-127.

Hammarström H., Forkel R., Haspelmath M., Nordhoff S. (2014), Glottolog 2.3, Leipzig, wersja on-line: http://glottolog.org (dostęp: 19 grudnia 2015).

Kamińska T. (2006), Aborygeni Australii, Rzeszów, wersja on-line: http://www.tatianakaminska. com/home2 (dostęp: 19 grudnia 2015).

Lewis M.P., Simons G.F., Fennig Ch.F. (red.) (2014), Ethnologue: Languages of the World, Seventeenth edition, Dallas, Texas, wersja on-line: http://www.ethnologue.com (dostęp: 15 grudnia 2014).

Mathews R.H. (1902), Languages of some native tribes of Queensland, New South Wales and Victoria: Yualeai, „Journal of the Royal Society of New South Wales” 36, s. 135-190.

Mathews R.H. (1903), Languages of the Kamilaroi and other Aboriginal tribes of New South Wales, „Journal of the Royal Anthropological Institute” 33, s. 259-283.

Ridley W. (1855), On the Kamilaroi Language of Australia, „Transactions of the Philological Society", s. 72-84.

Ridley W. (1856), On the Kamilaroi tribe of Australians and their dialect, „,ournal of the Ethnological Society of London" 4, s. 285-293.

Ridley W. (1875), Kamilaroi and Other Australian Languages, Sydney.

Stockton E. (2008), Dar Aborygenów. Duchowość dla Australijczyków, Warszawa.

Troy J., Walsh M. (2010), A linguistic renaissance in the South East of Australia, [w:] Endangered Austronesian and Aboriginal Languages. Essays on Language Documentation, Archiving and Revitalization, red. G. Senft, Canberra, s. 175-182.

Walsh M. (1993), Languages and their status in Aboriginal Australia, [w:] Language and Culture in Aboriginal Australia, red. M. Walsh, C. Yallop, Canberra, s. 1-14.

Wierzbicka A. (2010), Experience, Evidence, and Sense. The Hidden Cultural Legacy of English, Oxford.

Wierzbicka A. (2014), Imprisoned in English. The Hazards of English as a Default Language, Oxford.

Williams C. (1980), A Grammar of Yuwaalaraay, Canberra.

Yuwaalaraay gaay, Gamilaraay garay, http://www.yuwaalaraay.org (dostęp: 19 grudnia 2015). 
Zuckermann G. (2013), Historical and moral arguments for language reclamation, „History and Philosophy of the Language Sciences”, http://hiphilangsci.net/2013/06/26/historical-and-moral-arguments-for-language- reclamation (dostęp: 19 grudnia 2015).

Zuckermann G., Shakuto-Neoh S., Quer G.M. (2014), Native Tongue Title: Compensation for the loss of Aboriginal languages, „Australian Aboriginal Studies” 1, s. 55-71.

Zuckermann G., Walsh M. (2011), Stop, revive, survive: Lessons from the Hebrew revival applicable to the reclamation, maintenance and empowerment of Aboriginal languages and cultures, „Australian Journal of Linguistics” 31.1, s. 111-127.

\section{Sleeping languages, a few remarks on the linguistic situation of Aboriginal people in Australia (through the specific case of Gamilaraay, an Aboriginal language of New South Wales)}

\section{Summary}

The main aim of this article is to investigate revival linguistics, a new branch of linguistics as yet little known in Poland, through the specific case of the recent revival of Gamilaraay, an Aboriginal language of New South Wales, Australia. After discussing the classification of the world's languages according to their vitality, the author presents the language situation in Australia and offers a definition of revival linguistics, justifying its relevance to the revitalization of Aboriginal languages, including some that have been extinct for up to two hundred years.

Keywords: revival linguistics, Gamilaraay, extinct languages, sleeping languages, language reclamation 